\title{
Analysis, Design and Estiamation of High Rised RCC Residential Apartment (S+G+10) by using Staad. Pro Software
}

\author{
N. Krithi, B. Venkata Siva, T Pradeep Kumar, P V Vishnu Vardhan Reddy, T G N C Vamsi Krishna
}

\begin{abstract}
Civil Engineering Structures which are been constructed and are being constructed were mostly analysed and designed using STAAD.PRO software and the cost estimation is made in MS Excel. As both these tools have made the analysis, design and estimation an easier task. But in discussing about in favour of these, durability of many structures are failing in seismic zones. As to make this as a note many engineers and researchers are been struggling in solving the problem of failures in the construction Industry. Here, we are considering a method of response spectrum in ZONE-II. By considering this method would able to control the structure against failure to seismic loads. Then while on coming to estimation of the structure, the only thing that worries is when execution started the cost either may increases or may decreases. We, in this research paper have given the factors that influence the change in cost of project on pre-construction and post construction.
\end{abstract}

Keywords: Residential Apartment, Earthquake loads, Estimation, Zone -II, Pre-construction, Post construction.

\section{INTRODUCTION}

$\mathrm{O}_{\text {ne of the foremost terrifying and destructive }}$ phenomena of nature may be a serious seismic tremor and its appaling delayed consequences. An seismic tremor could be a sudden development of the soil, caused by the sudden discharge of strain that has collected over a long time. For hundreds of millions of a long time, the powers of plate tectonics have formed the soil as the tremendous plates that shape the earths surface gradually move over, beneath, and past each other. Some of the time the development is slow. At other times, the plates are bolted together, incapable to discharge the collecting vitality. When the gathered vitality develops slid sufficient, the plates break free. In case the seismic tremor happens in a populated zone, it may cause numerous passing and wounds and broad property harm.

Manuscript received on August 18, 2021.

Revised Manuscript received on August 28, 2021.

Manuscript published on September 30, 2021

N. Krithi, Student, Department of Civil Engineering, Chalapathi Institute of Engineering and Technology (CIET), Guntur (A.P), India. E-mail: nallapanenikrithi@gmail.com

B. Venkata Siva, Student, Department of Civil Engineering, Chalapath Institute of Engineering and Technology (CIET), Guntur (A.P), India. Email: sivachowdaryboyalla@gmail.com

T Pradeep Kumar, Student, Department of Civil Engineering, Chalapathi Institute of Engineering and Technology (CIET), Guntur (A.P), India. E-mail: tadavarthipradeep@gmail.com

P V Vishnu Vardhan Reddy, Student, Department of Civil Engineering, Chalapathi Institute of Engineering and Technology (CIET), Guntur (A.P), India. E-mail: vishnureddy06412@gmail.com

T G N C Vamsi Krishna, Assistant Professor, Department of Civil Engineering, Chalapathi Institute of Engineering and Technology (CIET), Guntur (A.P), India. E-mail: tgncvamsikrishna@gmail.com

(C) The Authors. Published by Blue Eyes Intelligence Engineering and Sciences Publication (BEIESP). This is an open access article under the CC BY-NC-ND license (http://creativecommons.org/licenses/by-nc-nd/4.0/)
Now a days we are challenging the presumption the seismic tremors must display an wild and erratic danger to life and property. Researchers have started to assess the areas and likelihoods of future harming seismic tremors. Planning the budget of the complete extend is known as estimation. Moreover known as determining of budget. Estimation changes depending upon the variables advertise rate of the materials labor charges and over - rate expenses. But, other than these there's a major figure that impacts the estimation is point of view of individuals included budget.

\subsection{Seismology}

Seismology is the think about of seismic tremors and seismic waves that move through and around the soil. A seismologist could be a researcher who studies about seismic tremors and waves.

P Waves: The primary kind of body wave is the $\mathrm{P}$ wave or essential wave. Usually the quickest kind of seismic wave, and thus, the primary to 'arrive' at a seismic satation. The $\mathrm{P}$ wave can move through strong shake and liquids, like water or the liquid layers of soil. It pushes and pulls the shake it moves through a bit like sound waves thrust and drag the discuss.

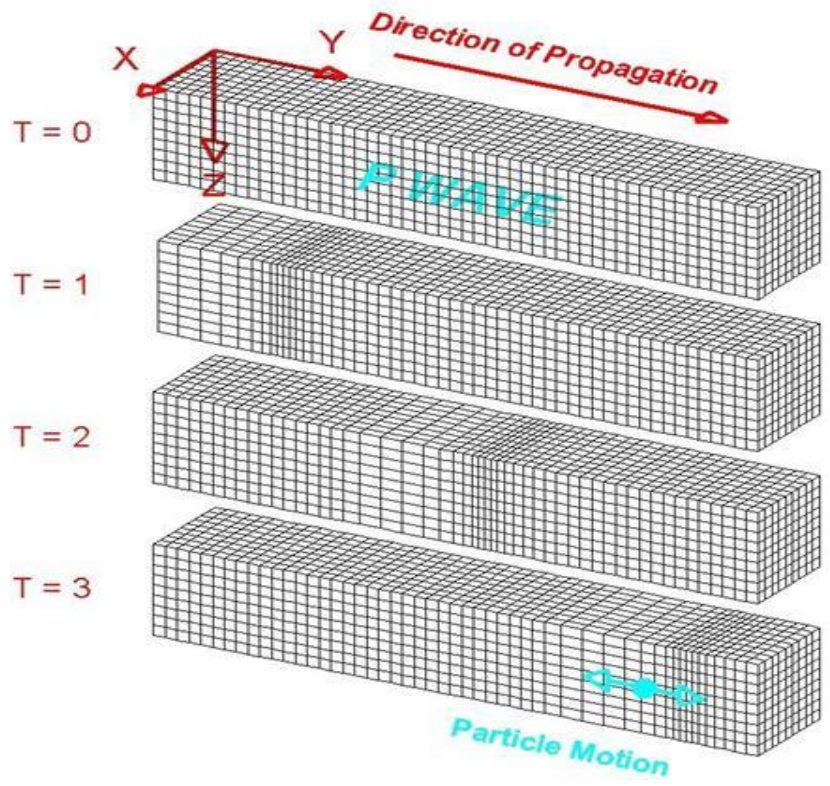

Figure 1 Particle motion of $\mathbf{P}$ Waves

ii. S Waves: The moment sort of body wave is the $\mathrm{S}$ wave or auxiliary wave, which is the moment wave you're feeling in an seismic tremor.
Published By: Blue Eyes Intelligence Engineering

and Sciences Publication

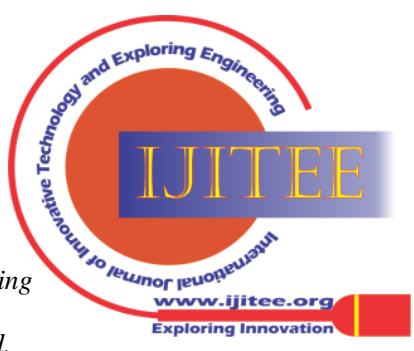


An S wave is slower than a $\mathrm{P}$ wave and can as it were move through strong shake, not through any fluid medium. It is this property of $\mathrm{S}$ waves that driven seismologists to conclude that the earth's external centre could be a fluid. S waves move shake particles up and down, or side - to - side perpendicular to the course that the wave is travelling within (the course of wave

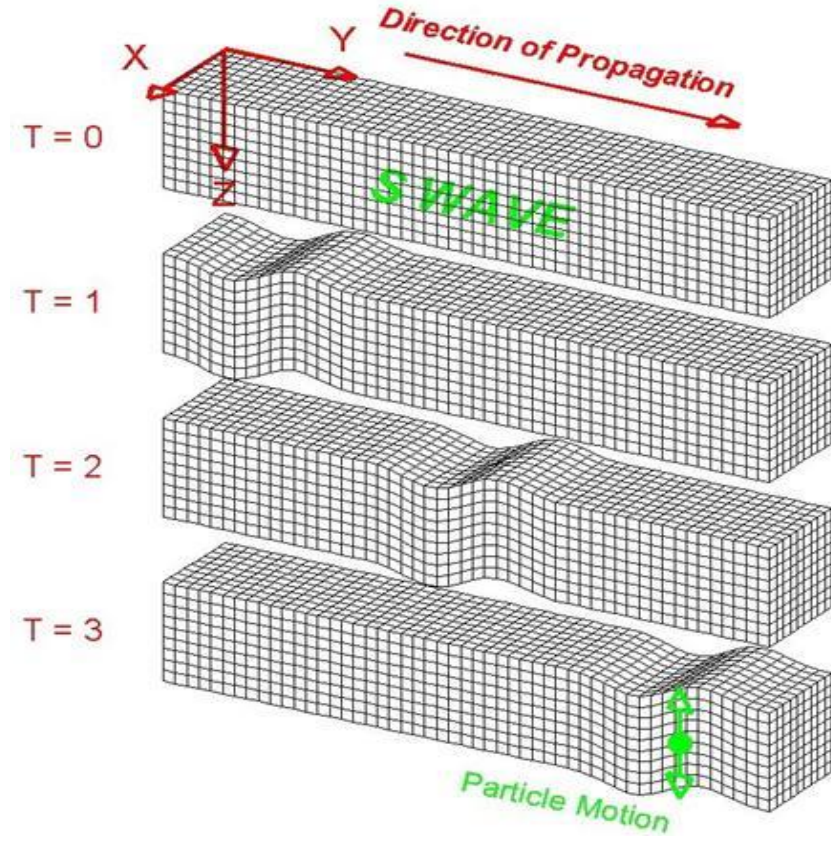

Figure 2 Particle motion of $S$ Waves

iii. Love Waves: It is the first form of surface wave. These love waves are named after A. E. H Love. The british mathematician who worked out to find the the mathematical model for this form of wave in 1911. This Love wave is the fastest surface wave moving the ground from side - to - side.

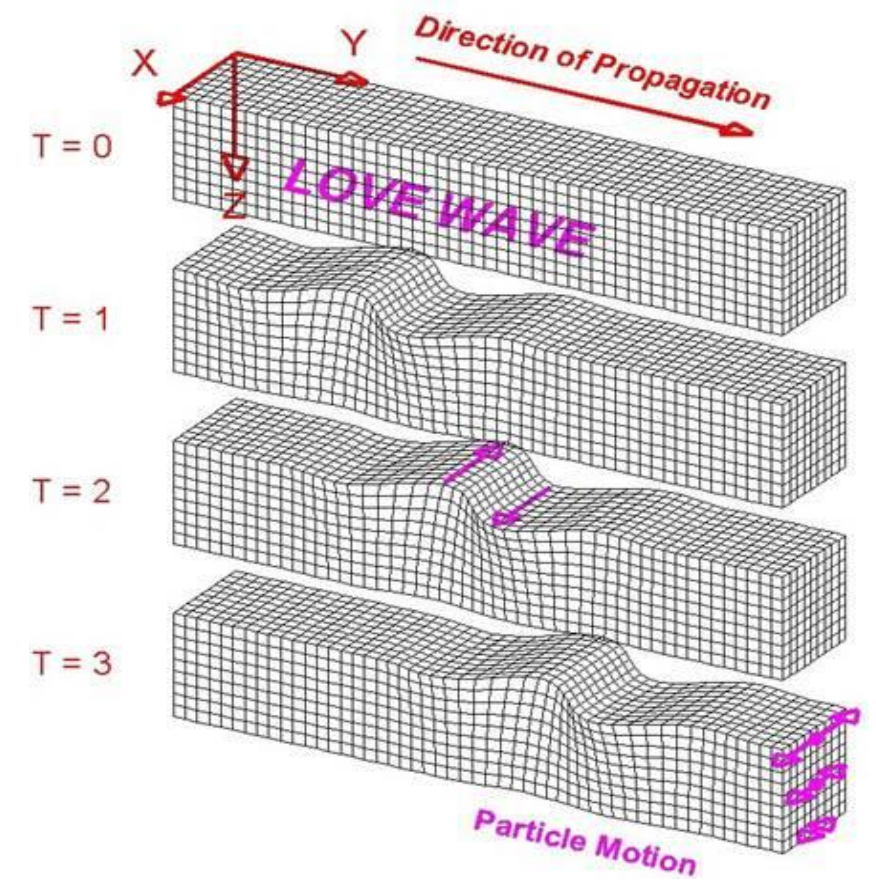

Figure 3 Particle motion of love waves

iv. Rayleigh Waves: the other kind of surface wave is the rayleigh wave named for john william strutt, lord rayleigh, who numerically anticipated the presence of this kind of wave in 1885. A wave rolls over a lake or sea. Since, it rolls, it moves the ground up and down and side - to - side with in the same heading that the wave is moving.

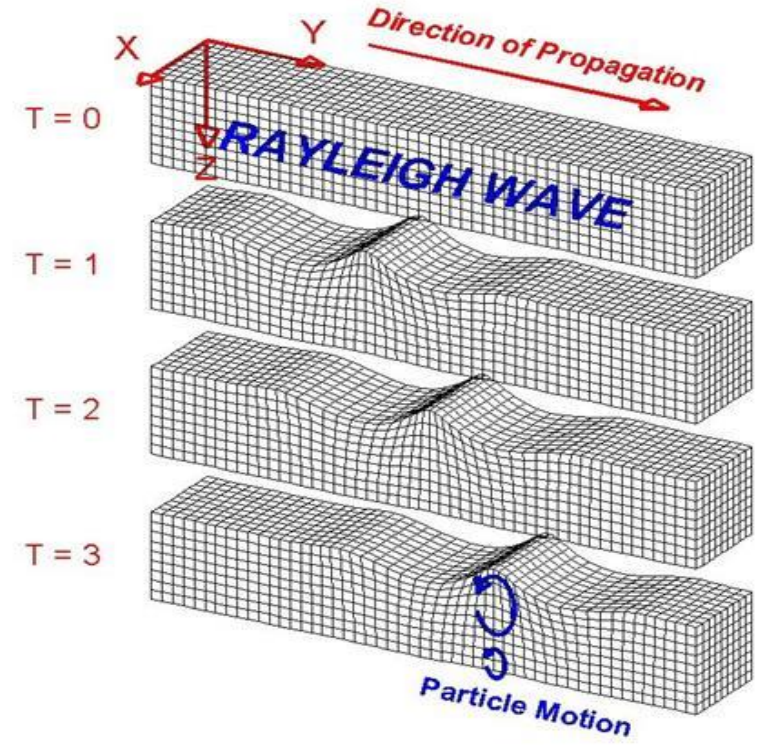

Figure 4 Particle motion of $R$ waves

\section{METHODOLOGY}

Every nation carries out mapping of its territory based on all natural disasters like earthquake, cyclone, flood and volcano etc.. This mapping is done on the basis of past history and factors responsible for such disaster of present in that area. This mapping helps people to design their home and other infrastructure so that they don't become the victim of such disaster and can withstand disasters with as minimum as possible loss of life and property. Code of practice of all nations for design of buildings and other structure recommended design guidelines based on such mapping or zoning.

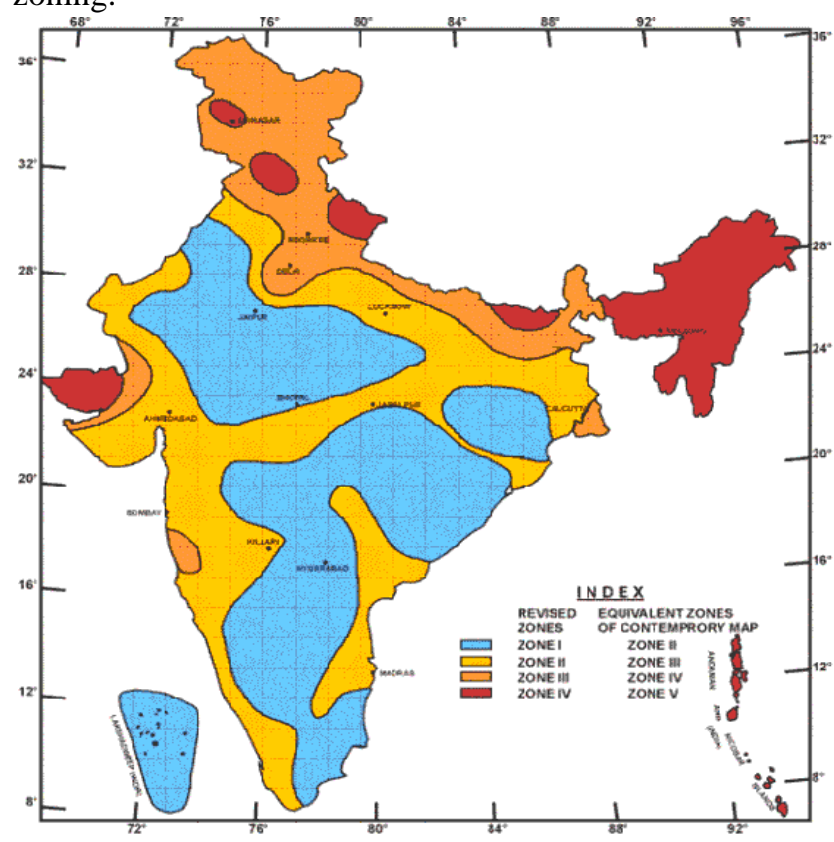

Figure 5 Different Zones of India

Published By:

Blue Eyes Intelligence Engineering and Sciences Publication

(C) Copyright: All rights reserved.

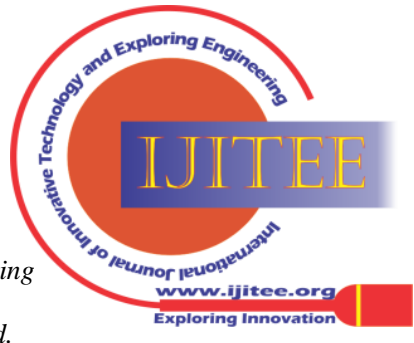




\section{A) Load Calculations:}

Dead loads: Dead load alludes to loads that generally don't change over time, such as the weight of all lasting components of a building counting dividers, bars, columns, flooring fabric etc. settled lasting gear and fitting that are an fundamentally portion of the structure HVAC (Heating, Ventilation and Air Conditioning) etc., The dead loads are calculated from the part sizes and evaluated fabric densities. Unit weight of building materials can be assessed according to IS 875 (Part - 1)

\section{Dead load calculations}

Self- weight o slab $=0.15 * 25=3.75 \mathrm{kn} / \mathrm{m}^{2}$

Exterior wall $\quad=9$ inch

$$
=9 * 2.5
$$$$
=22.5 \mathrm{~cm}
$$

$$
=225 \mathrm{~mm}
$$

Interior wall

$$
=6 \text { inch }
$$$$
=6 * 2.5
$$$$
=15 \mathrm{~cm}
$$$$
=150 \mathrm{~mm}
$$

Parapet wall$$
=4 \text { inch }
$$$$
=4 * 2.5
$$$$
=10 \mathrm{~cm}
$$$$
=100 \mathrm{~mm}
$$

Self -weight of exterior wall $=0.225 * 3.35 * 20$

$$
=15 \mathrm{KN} / \mathrm{m}
$$

Height of wall $=3.35 \mathrm{~m}$

Self- weight of partition wall $=0.15 * 3.35 * 20$

$$
=10 \mathrm{KN} / \mathrm{m}
$$

Self -weight of parapet wall $=0.1 * 1 * 20$

$$
=2 \mathrm{KN} / \mathrm{m}
$$

Plastering:

$$
\begin{aligned}
& =0.02 * 3.35 * 18 * 2 \\
& =2.41 \mathrm{KN} / \mathrm{m}
\end{aligned}
$$

Exterior wall $=15+2.41$

$$
=17.41 \mathrm{KN} / \mathrm{m}
$$

Interior wall $=10+2.41 \mathrm{KN} / \mathrm{m}$

$$
=12.41 \mathrm{KN} / \mathrm{m}
$$

Parapet wall $=2+0.72$

$$
=2.72 \mathrm{KN} / \mathrm{m}
$$

Live loads: Refers to loads that do, or can, alter over time, such as individuals strolling around a buildings (inheritance) or movable objects such as furniture. Live loads are variable as they depend on usage and capacity in any case, plan codes can give comparable loads for different structures loads prescribed by codes are experimental and traditional based on involvement and acknowledged practice. IS: 875 Part 2 deals with forced loads on buildings delivered by the expecting inheritance or utilize.

\section{Live load calculation}

Floor load $=4 \mathrm{KN} / \mathrm{m}^{2}$

Roof load $=2 \mathrm{KN} / \mathrm{m}^{2}$

\section{Seismic loads}

Seismic load is one of the essential concepts of seismic tremor building which suggests the application of an earthquake - generated disturbance to a buildings structure either with the ground, or with adjoining structures, or with gravity waves from tsunami. IS: 1893:2002/2005: Seismic loads

\section{Seismic weight calculation:}

$\mathrm{W}=$ dead load $+50 \%$ of live load

$\mathrm{Ta}=0.09 \mathrm{H} /$ square root of $\mathrm{D}$

$\mathrm{H}=24 \mathrm{~m}$

$\mathrm{D}=$ base dimensions $(12 \mathrm{~m} * 12 \mathrm{~m})$

$\mathrm{Ta}=0.62 \mathrm{sec}$

\section{Combination of loads}

Combinations of loads utilized for admissible stretch plan and extreme quality plan are to be taken based on benefit life, significance, disappointment result for a building and the properties of each stack such as inconstancy, event recurrence and length time and plan loads calculated by the return period transformation.

\section{Load combinations}

$$
\begin{aligned}
& \text { 1.5(DL+LL) } \\
& 1.2(\mathrm{DL}+\mathrm{LL}+\mathrm{EQX}) \\
& 1.2(\mathrm{DL}+\mathrm{LL}-\mathrm{EQX}) \\
& 1.2(\mathrm{DL}+\mathrm{LL}+\mathrm{EQZ}) \\
& 1.2(\mathrm{DL}+\mathrm{LL}-\mathrm{EQZ}) \\
& 1.5(\mathrm{DL}+\mathrm{EQX}) \\
& 1.5(\mathrm{DL}-\mathrm{EQX}) \\
& 1.5(\mathrm{DL}+\mathrm{EQZ}) \\
& 1.5(\mathrm{DL}-\mathrm{EQZ})
\end{aligned}
$$

B) Model Generation

Analysis of Multi- Storey Building is done with help of Staad.Pro Software

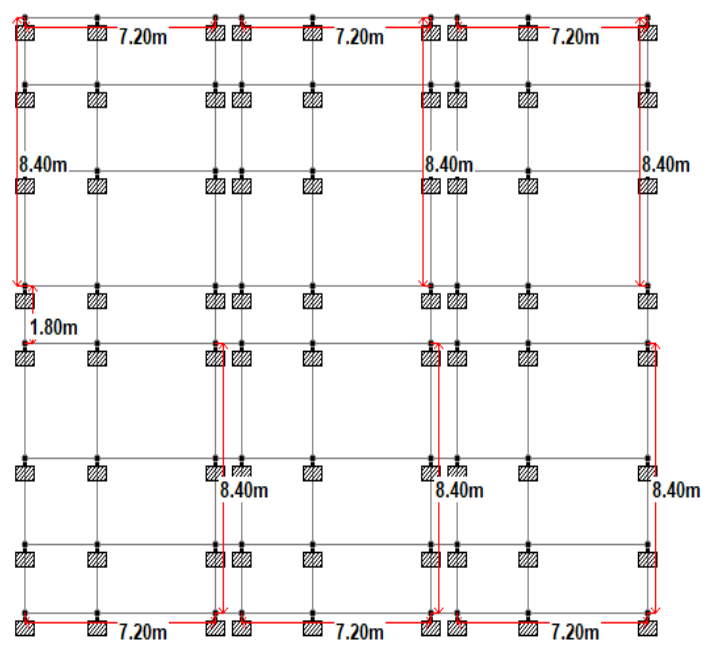

Figure 6 Plan of Structure

\begin{tabular}{|c|c|l|l|l|l|}
\hline Section & $0.0 \mathrm{~mm}$ & $1125.0 \mathrm{~mm}$ & $2250.0 \mathrm{~mm}$ & $\begin{array}{c}3375.0 \\
\mathrm{~mm}\end{array}$ & $\begin{array}{c}4500.0 \\
\mathrm{~mm}\end{array}$ \\
\hline Top & 277.85 & 0.00 & 0.00 & 753.48 & 2124.99 \\
\hline Reinf. & $($ Sq. $\mathrm{mm})$ & $\begin{array}{c}(\mathrm{Sq} . \\
\mathrm{mm})\end{array}$ & $\begin{array}{c}(\mathrm{Sq} . \\
\mathrm{mm})\end{array}$ & $\begin{array}{c}\text { (Sq. } \\
\mathrm{mm})\end{array}$ & (Sq. $\mathrm{mm})$ \\
\hline Bottom & 1524.86 & 855.91 & 244.25 & 244.25 & 481.89 \\
\hline Reinf. & $(\mathrm{Sq} . \mathrm{mm})$ & $\begin{array}{c}(\mathrm{Sq} . \\
\mathrm{mm})\end{array}$ & $\begin{array}{c}(\mathrm{Sq} . \\
\mathrm{mm})\end{array}$ & $\begin{array}{c}\text { (Sq. } \\
\mathrm{mm})\end{array}$ & (Sq. $\mathrm{mm})$ \\
\hline
\end{tabular}

Published By:

Blue Eyes Intelligence Engineering and Sciences Publication

(C) Copyright: All rights reserved. 


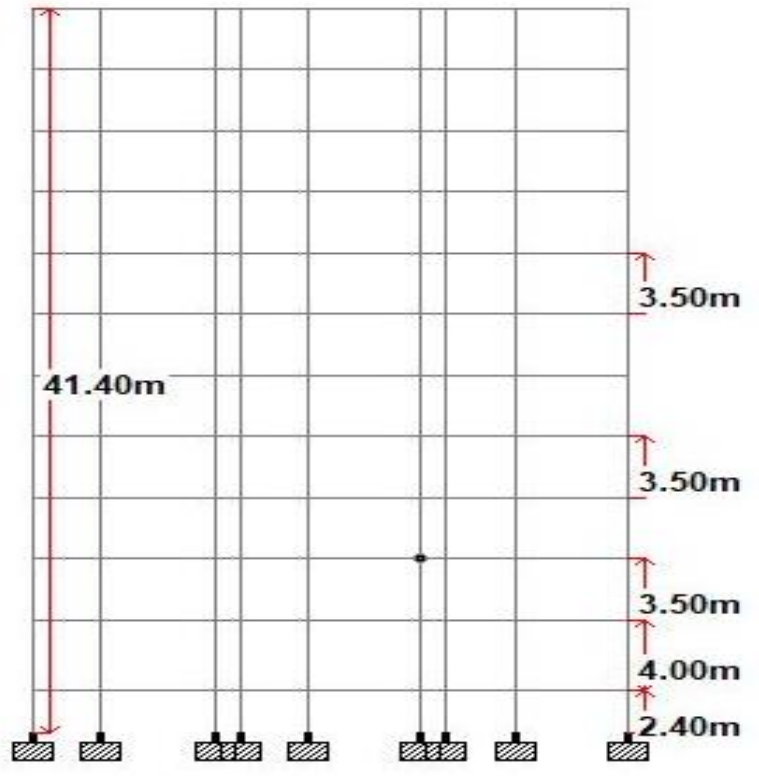

Figure 7 Elevation of Structure

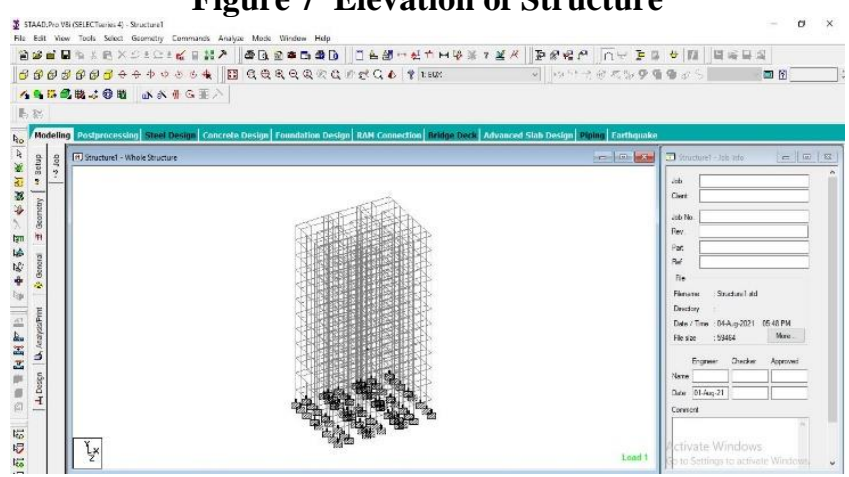

Figure 8 Isometric view of structure

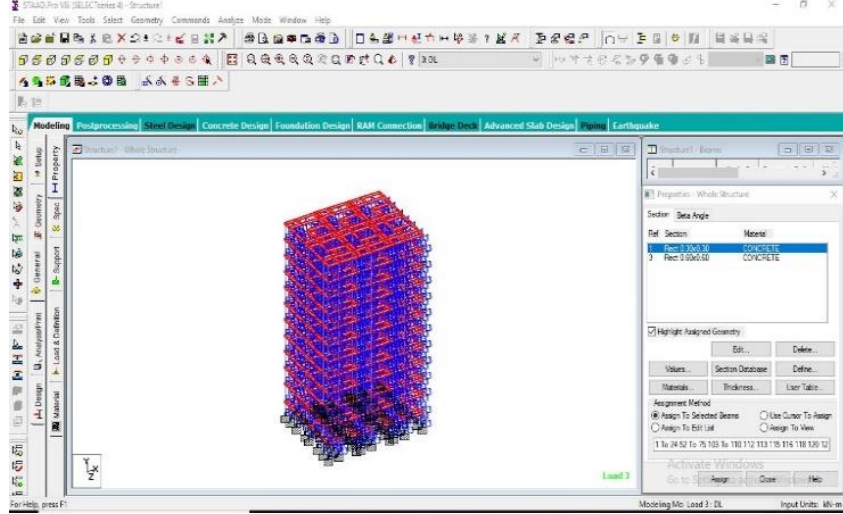

Figure 9 Beams assigning to structure

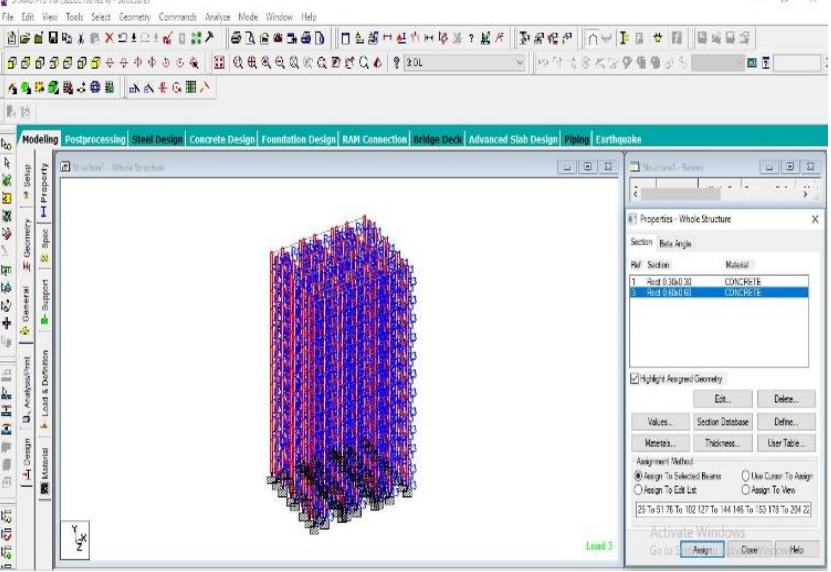

Figure 10 Columns assigning to Structure

Retrieval Number: 100.1/ijitee J944508101021

DOI: 10.35940/ijitee.J9445.09101121

Journal Website: www.ijitee.org

\section{RESULTS AND DISCUSSION}

As it is difficult to present and discuss about all the components of the structure. So, here we are about to discuss the major beam and columns of the structure and they are in the following figures.

Beam No. 5 Design Results

M30 Fe415 (Main) Fe415 (Sec.) LENGTH: 4500.0 mm COVER: $25.0 \mathrm{~mm}$

SUMMARY OF REINF. AREA (Sq.mm)

SUMMARY OF PROVIDED REINF. AREA

\begin{tabular}{|c|c|c|c|c|c|}
\hline Section & $0.0 \mathrm{~mm}$ & $1125.0 \mathrm{~mm}$ & $2250.0 \mathrm{~mm}$ & $3375.0 \mathrm{~mm}$ & $4500.0 \mathrm{~mm}$ \\
\hline Top & 4-12í & 2-12í & 2-12í & 7-12í & 19-12í \\
\hline Reinf. & 1 layer(s) & 1 layer(s) & 1 layer(s) & 1 layer(s) & 2 layer(s) \\
\hline Bottom & 5-20í & 3-20í & 3-20í & 3-20í & 3-20í \\
\hline Reinf. & 1 layer(s) & 1 layer(s) & 1 layer(s) & 1 layer(s) & 1 layer(s) \\
\hline Shear & $\begin{array}{c}2 \text { legged } \\
81 ́ \\
\end{array}$ & $\begin{array}{c}2 \text { legged } \\
81 ́\end{array}$ & $\begin{array}{c}2 \text { legged } \\
81 ́\end{array}$ & $\begin{array}{c}2 \text { legged } \\
81 ́\end{array}$ & 2 legged 81 \\
\hline Reinf. & @ $150 \mathrm{~mm}$ & $\begin{array}{c}\text { @ } 150 \mathrm{~mm} \\
\mathrm{c} / \mathrm{c}\end{array}$ & $\begin{array}{c}\text { @ } 150 \mathrm{~mm} \\
\mathrm{c} / \mathrm{c}\end{array}$ & @ $150 \mathrm{~mm}$ & @ $150 \mathrm{~mm}$ \\
\hline
\end{tabular}

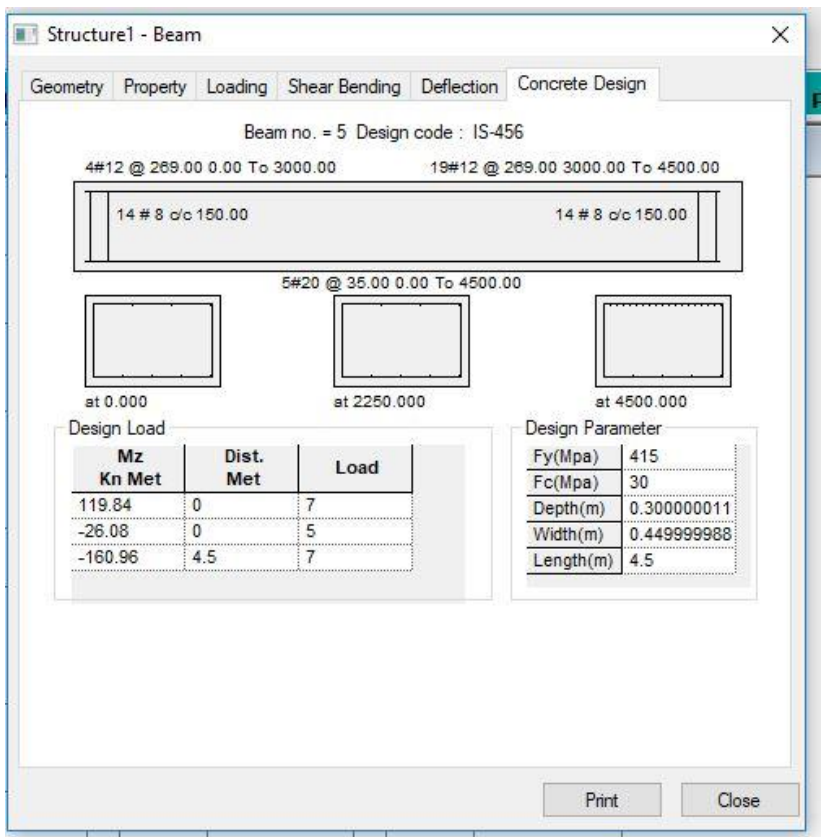

Figure 11 Detailing of Beam No. 5

Beam No. 2829 Design Results

M30 Fe415 (Main) Fe415 (Sec.)

LENGTH: $3600.0 \mathrm{~mm}$

SIZE: $\quad 450.0 \mathrm{~mm}$

X $300.0 \mathrm{~mm}$ COVER: $25.0 \mathrm{~mm}$

SUMMARY OF REINF. AREA (Sq.mm)

\begin{tabular}{|c|c|l|l|l|c|}
\hline Section & $0.0 \mathrm{~mm}$ & $900.0 \mathrm{~mm}$ & $1800.0 \mathrm{~mm}$ & $2700.0 \mathrm{~mm}$ & $\begin{array}{c}3600.0 \\
\mathrm{~mm}\end{array}$ \\
\hline Top & 0.00 & 0.00 & 0.00 & 728.77 & 1853.06 \\
\hline Reinf. & (Sq. $\mathrm{mm})$ & $($ Sq. $\mathrm{mm})$ & $($ Sq. $\mathrm{mm})$ & $($ Sq. $\mathrm{mm})$ & (Sq.mm) \\
\hline Bottom & 1517.07 & 755.79 & 248.86 & 0.00 & 147.75 \\
\hline Reinf. & (Sq. $\mathrm{mm})$ & $($ Sq. $\mathrm{mm})$ & $($ Sq. $\mathrm{mm})$ & $($ Sq. $\mathrm{mm})$ & (Sq.mm) \\
\hline
\end{tabular}

Published By:

Blue Eyes Intelligence Engineering and Sciences Publication

(C) Copyright: All rights reserved.

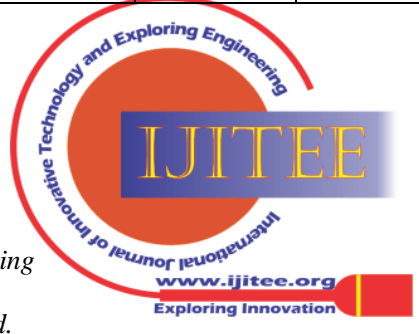


SUMMARY OF PROVIDED REINF. AREA

\begin{tabular}{|c|c|c|c|c|c|}
\hline Section & $0.0 \mathrm{~mm}$ & $900.0 \mathrm{~mm}$ & $1800.0 \mathrm{~mm}$ & $2700.0 \mathrm{~mm}$ & $\begin{array}{c}3600.0 \\
\mathrm{~mm}\end{array}$ \\
\hline Top & 2-20í & 2-20í & 2-20í & 3-20í & 6-20í \\
\hline Reinf. & 1 layer(s) & 1 layer(s) & 1 layer(s) & 1 layer(s) & 1 layer(s) \\
\hline Bottom & 5-20í & 3-20í & 3-20í & 2-20í & 3-20í \\
\hline Reinf. & 1 layer(s) & 1 layer(s) & 1 layer(s) & 1 layer(s) & 1 layer(s) \\
\hline Shear & $\begin{array}{l}2 \text { legged } \\
81 ́\end{array}$ & 2 legged $8 i ́$ & 2 legged 81 & 2 legged 81 & $\begin{array}{c}2 \text { legged } \\
81 ́\end{array}$ \\
\hline Reinf. & $\begin{array}{r}150 \mathrm{~mm} \\
\mathrm{c} / \mathrm{c}\end{array}$ & $\begin{array}{c}\text { @ } 150 \mathrm{~mm} \\
\mathrm{c} / \mathrm{c}\end{array}$ & $\begin{array}{c}\text { @ } 150 \mathrm{~mm} \\
\mathrm{c} / \mathrm{c}\end{array}$ & $\begin{array}{c}\text { @ } 150 \mathrm{~mm} \\
\mathrm{c} / \mathrm{c}\end{array}$ & $\begin{array}{c}\text { @ } 150 \mathrm{~mm} \\
\mathrm{c} / \mathrm{c}\end{array}$ \\
\hline
\end{tabular}

SHEAR DESIGN RESULTS AT DISTANCE d (EFFECTIVE DEPTH) FROM FACE OF THE SUPPORTSHEAR DESIGN RESULTS AT $565.0 \mathrm{~mm}$ AWAY FROM START SUPPORT

VY $=\quad-56.38 \mathrm{MX}=\quad-0.9$

Provide 2 Legged 10í @ 150 mm c/c

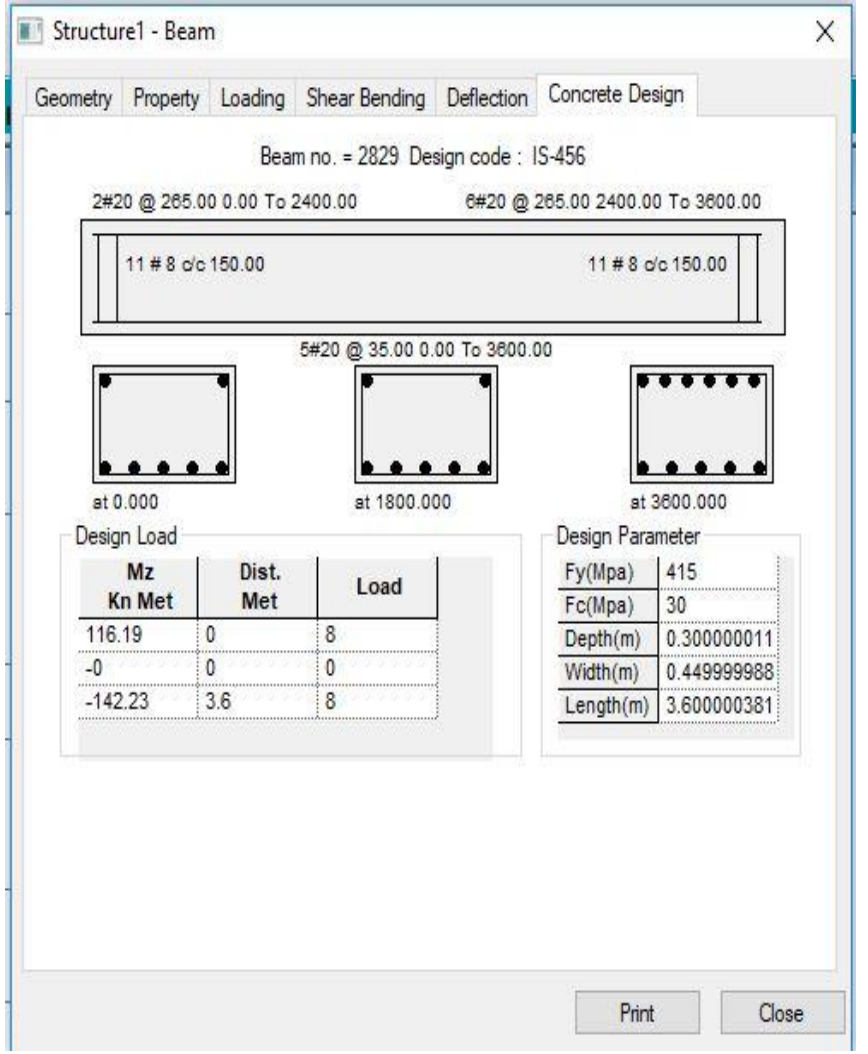

Figure 12 Detailing of Beam 2829

\section{Column No.25 Design Results}

M30 Fe415 (Main) Fe415 (Sec.) LENGTH: $2400.0 \mathrm{~mm}$ CROSS SECTION: $600.0 \mathrm{~mm}$ X $600.0 \mathrm{~mm}$ COVER: $40.0 \mathrm{~mm}$

** GUIDING LOAD CASE: 2 END JOINT:

1 TENSION COLUMN

REQD. STEEL ARE: 12629.66 Sq.mm. REQD. CONCRETE AREA: 347370.34 Sq.mm.

MAIN REINFORCEMENT: Provide 28 - 25 dia. (3.82\%, 13744.47 Sq.mm.)

(Equally distributed)

TIE REINFORCEMENT: Provide $8 \mathrm{~mm}$ dia. rectangular ties@300mm c/c

SECTION CAPACITY BASED ON REINFORCEMENT REQUIRED (KNS-MET)
Puz:

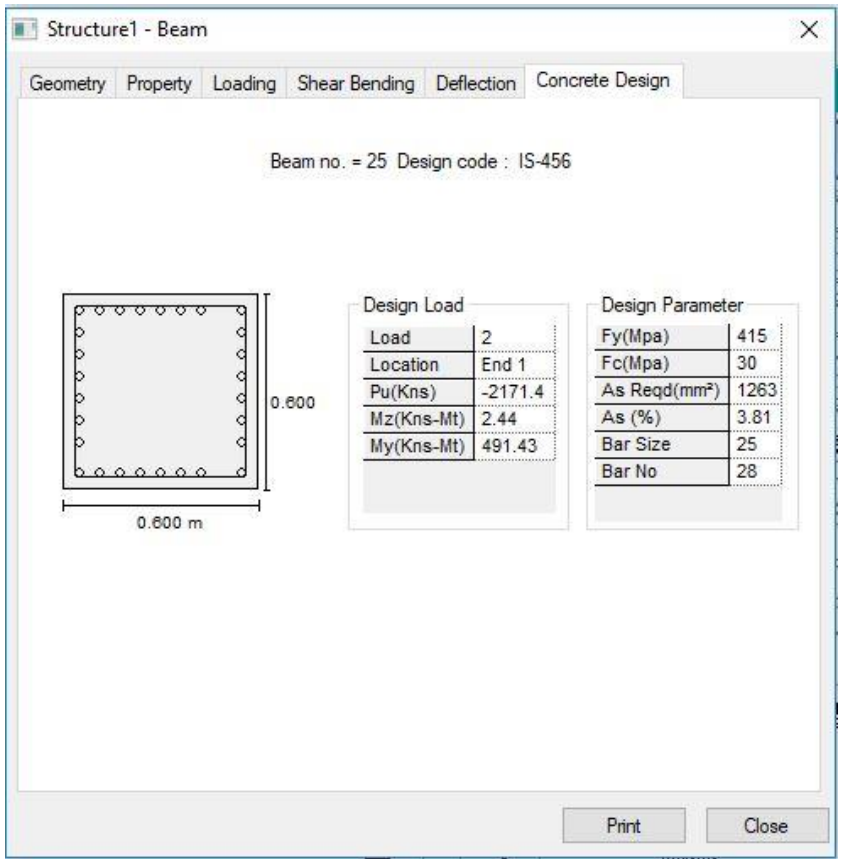

Figure 13 Detailing of column 25

\section{COST ESTIMATION}

Here, in this scenario the total budget is of Rs. 52941866.3/the cost is taken out from the SSR of Andhra Pradesh 2021.

1. Getting the materials of cheap quality with low cost.

2. Concentration on money.

3. Allocation of labor.

4. Supervision charges from the contractor.

5. Lack of supervision from the client

(1) Low Cost low quality: Cost of poor quality (COPQ) or poor quality costs (PQC), are costs that would disappear if systems, processes, and products were perfect. In view of saving money or profiting money the contractor may go to purchase low-cost materials which lack kin quality.

(2) Concentration on money: cash concentration a technique of making all the money that is spent on different items of work are make together as a single budget amount. By this there is an advantage in showing the spending on project report as a huge amount which results on more money from the client company.

(3) Allocation of labor: According to NBC report there is a data regarding the work force of labor as how much work can be done per a day by certain number of people. Client allocates the labor according to NBC but where if it comes to contractor he manages to do the work with only few labor with or without disturbing the quality of project. If we look into the rate analysis of the contractor view, the allocation is less when compared to client viewed analysis.

(4) Charges from contractor: there would be different charges for men who work in the site for different works. This depends on the locality of availability of labor for example: the cost of a mason in A.P is Rs.700/day and labor costs Rs.500/day.

Published By:

Blue Eyes Intelligence Engineering and Sciences Publication

(C) Copyright: All rights reserved.

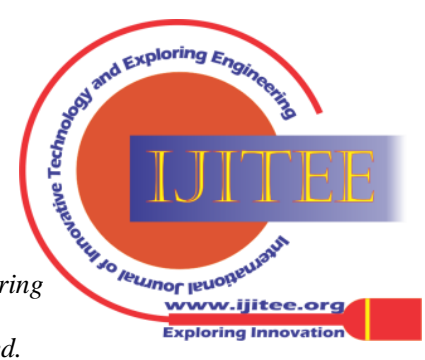


But, whereas in Chhattisgarh you get the cheapest labor all over India with a cost of just Rs. 500/day for mason and Rs. 250/day for a labor.

(5) Lack of supervision: Not only all the flaws from the contractors side. Client too has some demerits like lack of supervision. Every construction project needs supervision by a technical person from the both sides of a contract. But, when any one fails to holds this there the quality gets decreases and entry of cheap and low quality materials happens in the project.

Table- I: Name of the Table that justify the values

\begin{tabular}{|c|c|c|c|l|}
\hline S. No. & Description & Quantity & Cost & \multicolumn{1}{c|}{ Remarks } \\
\hline 1. & Total Cost (Except Steel) & - & Rs. 49217386/- & $\begin{array}{l}\text { All the items of work are calculated in } \\
\text { detail without steel. Where, steel is } \\
\text { calculated separately. }\end{array}$ \\
\hline 2. & Steel & 532.64MT & Rs. 37244480/-- $\begin{array}{l}\text { Total steel required for the project } \\
\text { includes Main bars, stirrups, hooks and } \\
\text { other required bars. }\end{array}$ \\
\hline \multicolumn{2}{|c|}{ Total Cost } & \multicolumn{1}{c|}{ Rs. 52941866.3/- } \\
\hline
\end{tabular}

\section{CONCLUSION}

1. This study explains the importance of earthquakes, how we can measure the earthquakes and impact of earthquakes on human life.

2. In this present study explains the reinforcement detailing for multi-storey structure at Zone-II region.

3. The considered structure is Irregular structure, when this structure is subjected to earthquakes the behavior of the structure is different from other regular structures. So, at that time we provide special reinforcement arrangement which is included in our study.

The above suggested conclusion is for structural design which we had for the structure. Now let us have a concluded report for the estimated budget of this particular project. The reality, and the factors that helps in changing the cost are as follows:

1. The handling of quality management gets poor when the availability of material gets for cheap cost.

2. Lack in providing necessary engineering supervision.

All the above illustrations that are identified have some remedies which does not able to decrease the cost.

\section{REFERENCES}

1. "Structural Analysis and Design (STAAD Pro) software," Bentley Systems, Inc.

2. A. Baghchi, Evaluation of the Seismic Performance of Reinforced Concrete Buildings, Ottawa: Department of Civil and Environmental Engineering, Carleton University, 2001.

3. T. Cakir, "Evaluation of the effect of earthquake frequency content on seismic behavior of cantilever retaining wall including soil-structure interaction," Soil Dynamics and Earthquake Engineering, vol. 45, pp. 96-111, 2013.

4. S. K. Nayak and K. C. Biswal, "Quantification of Seismic Response of Partially Filled Rectangular Liquid Tank with Submerged Block," Journal of Earthquake Engineering, 2013.

5. "Pacific Earthquake Engineering Research Center: NGA Database," $2005 . \quad$ [Online]. Available: http://peer.berkeley.edu/nga/data?doi=NGA0185. [Accessed 2013].

6. IS 1893 (Part1), Indian Standard Criteria for Earthquake Resistant Design of Structures part-1, 6.1 ed., New Delhi 110002: Bureau of Indian Standards, 2002.

7. "Pacific Earthquake Engineering Research Center: NGA Database," $2005 . \quad$ [Online]. Available: http://peer.berkeley.edu/nga/data?doi=NGA0023. [Accessed 2013].

8. "Vibration Data El Centro Earthquake," [Online]. Available: http://www.vibrationdata.com/elcentro.htm. [Accessed 2013]. cost which is obtained may have changes when we go in

3. Improper allocation of men power as per NBC.

9. "Pacific Earthquake Engineering Research Center: NGA Database," $2005 . \quad$ [Online]. Available: http://peer.berkeley.edu/nga/data?doi=NGA0855. [Accessed 2013].

10. Dr. S Kanchana, Ms. S Janani,(2018) "A study on factors affecting estimation of construction project", International Research Journal of Engineering and Technology (IRJET),ISSN 2395-0056, , Volume 5, Issue 11; November 2018

11. O.A. K'Akumu, etc.,(2012) " Component ratios of new building costs in Nairobi: a contractors' perspective", Journal of Financial Management of Property and Construction (JFMPC), PP.222-234, , Volume 17, Issue 3; 2012

\section{AUTHORS PROFILE}

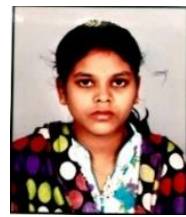

N. Krithi, IV Year UG Student Department of Civil Engineering from Chalapathi Institute of Engineering and technology (CIET), LAM, Guntur, Andhra Pradesh, India - 522034, E-mail : nallapanenikrithi@gmail.com

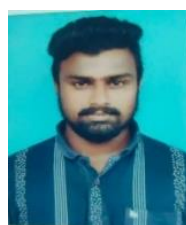

B. Venkata Siva, IV Year UG Student Department of Civil Engineering from Chalapathi Institute of Engineering and technology (CIET), LAM, Guntur, Andhra Pradesh, India - 522034, E-mail: sivachowdaryboyalla@gmail.com

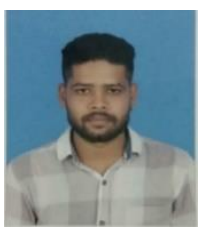

T Pradeep Kumar, IV Year UG Student Department of Civil Engineering from Chalapathi Institute of Engineering and technology (CIET), LAM, Guntur, Andhra Pradesh, India - 522034, E-mail: tadavarthipradeep@gmail.com

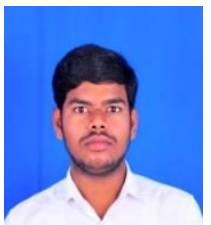

P V Vishnu Vardhan Reddy, IV Year UG Student, Department of Civil Engineering from Chalapathi Institute of Engineering and technology (CIET), LAM, Guntur, Andhra Pradesh, India - 522034, E-mail: vishnureddy06412@gmail.com

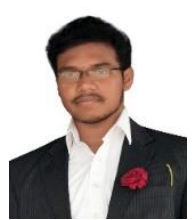

T G N C Vamsi Krishna, Assistant Professor, Department of Civil Engineering, Chalapathi Institute of Engineering and technology (CIET), LAM, Guntur, Andhra Pradesh, India - 522034, E-mail: tgncvamsikrishna@gmail.com

Published By: Blue Eyes Intelligence Engineering

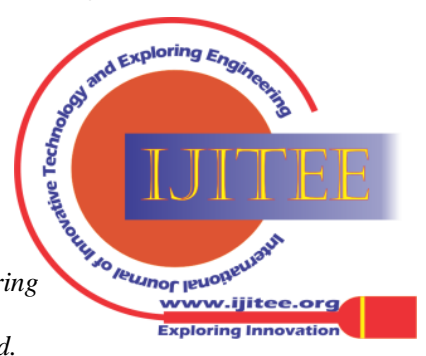

